University of New Hampshire

University of New Hampshire Scholars' Repository

Faculty Publications

8-10-1996

\title{
Dynamics of coupled diffusive and decompressive bubble growth in magmatic systems
}

\author{
Alexander A. Prusevich \\ University of New Hampshire, Durham, alex.proussevitch@unh.edu \\ Dork L. Sahagian \\ Lehigh University
}

Follow this and additional works at: https://scholars.unh.edu/faculty_pubs

\section{Comments}

This is an article published by AGU in Journal of Geophysical Research: Solid Earth in 1996, available online:

https://dx.doi.org/10.1029/96JB01342

\section{Recommended Citation}

Proussevitch, A. A., \& Sahagian, D. L. (1996). Dynamics of coupled diffusive and decompressive bubble growth in magmatic systems. Journal of Geophysical Research: Solid Earth, 101(B8), 17447-17455. doi:10.1029/96JB01342

This Article is brought to you for free and open access by University of New Hampshire Scholars' Repository. It has been accepted for inclusion in Faculty Publications by an authorized administrator of University of New Hampshire Scholars' Repository. For more information, please contact Scholarly.Communication@unh.edu. 


\title{
Dynamics of coupled diffusive and decompressive bubble growth in magmatic systems
}

\author{
Alexander A. Proussevitch and Dork L. Sahagian \\ Complex Systems Research Center, Institute for the Study of Earth, Oceans, and Space \\ University of New Hampshire, Durham
}

\begin{abstract}
Bubble growth in an ascending parcel of magma is controlled both by diffusion of oversaturated volatiles and decompression as the magma rises. We have developed a numerical model which explores the processes involved in water exsolution from basaltic and rhyolitic melts rising at a constant rate from magma chamber depths of 4 and $1 \mathrm{~km}$. While the model does not attempt to simulate natural eruptions, it sheds light on the processes which control eruptive behavior under various conditions. Ascent rates are defined such that a constant rate of decompression $d P / d t$ is maintained. A variety of initial ascent rates are considered in the model, from $1 \mathrm{~m} / \mathrm{s}$ to $100 \mathrm{~m} / \mathrm{s}$ for basalts, and from a few centimeters per second to $10 \mathrm{~m} / \mathrm{s}$ for rhyolite, at the base of the conduit. The model results indicate that for any reasonable ascent rate, basaltic melt degasses at a rate sufficient to keep the dissolved volatile concentration at equilibrium with the decreasing ambient pressure. Rhyolitic melt reaches the surface at equilibrium if its ascent rate is less than $1 \mathrm{~m} / \mathrm{s}$, but it can erupt with high oversaturation at greater ascent rates. The latter may lead to explosive eruptions. If the ascent rate of rhyolite is $10 \mathrm{~m} / \mathrm{s}$ or more, then melt barely degasses at all in the conduit and erupts with the highest oversaturation possible. For the case of slow magma rise, bubble growth is limited by decompression. For the case of rapid magma rise, bubble growth is limited by diffusion. The results of our simple model do not accurately simulate natural volcanic eruptions, but suggest that subsequent, more complex models may be able to simulate eruptions using the insights regarding diffusive and decompressive bubble growth processes explored in this study. Numerical modeling of volcanic degassing may eventually lead to better prediction of eruption timing, energetics and hazards of active volcanoes.
\end{abstract}

\section{Introduction}

Volcanic eruptions have been studied in recent years by various methods including experimental investigations of degassing [Jaupart and Vergniolle, 1988; Mader et al., 1994; Woods and Caufield, 1992], numerical modeling of eruption mechanisms [Sheridan and Wohletz, 1992; Trial et al., 1992], analytical formulations of magma chamber and conduit dynamics prior to eruption [Anderson, 1991; Dobran, 1992; Tait et al., 1989; Vergniolle and Jaupart, 1990], and the dynamics of eruptive columns after leaving the vent [Neri and Dobran, 1994; Sparks, 1986; Turcotte et al., 1990; Valentine et al., 1991; Wilson et al., 1980; Woods, 1988; Woods and Wohletz, 1991]. These have been recently summarized in the review of Sparks et al. [1994]. We have also attempted to contribute to the under-standing of eruptions by developing a numerical model of diffusive bubble growth in volcanic systems [Proussevitch et al., 1993b] because bubble growth plays a major role in controlling eruption behavior [Bottinga and Javoy, 1990a; Bottinga and Javoy, 1990b; Mangan et al., 1993; Sahagian and Anderson, 1991; Sparks, 1978; Thomas et al. , 1994; Toramaru, 1995]. Our preliminary work modeled bubble

Copyright 1996 by the American Geophysical Union.

Paper number 96JB01342.

0148-0227/96/96JB-01342\$09.00 evolution at constant pressure which revealed some important processes in oversaturation degassing. We now extend this model to include varying ambient (hydrostatic) pressure to determine the evolution of bubbles from nucleation at depth to eruption at the vent where the large size of growing bubbles can lead to foam disruption into gassy spray. We limit our present analysis to gradual decompression at a constant rate. This is an extremely conservative approach, because it does not account for the complex feedback between magma hydrodynamics and bubble growth, but even the constant decompression case serves to elucidate the important relations between decompression and diffusion during bubble growth.

Nucleation in the volcanic conduit is not considered in this study but has been addressed elsewhere [Hurwitz and Navon, 1994; Toramaru, 1989; Toramaru, 1995]. Nucleation of additional bubbles, as controlled by oversaturation, would tend to limit oversaturation by increasing bubble number density, thus imposing an overall effect roughly equivalent to increasing diffusivity. This is because additional bubbles between previous bubbles effectively reduces the diffusion distance of volatiles and allows more rapid growth of the total gas volume in the system relative to a case without any new nucleation. The net effect of nucleation would be to allow growth of the bubbles slightly earlier than otherwise and would cause the depth of maximum oversaturation to be greater, but the 
extent of oversaturation to be less. This is qualitatively the same as if higher diffusivity were used. While nucleation is surely a real process in natural volcanic systems, the additional degree of freedom allowed by nucleation obscures the details of the coupling between diffusive and decompressive bubble growth, the processes we wish to highlight in this paper.

Models of flow of magma and gas in energetic plinian eruptions [Dobran, 1992; Wilson et al., 1980] have assumed that the concentration of gas dissolved in the melt is always in equilibrium with the evolving pressure in the gas as the system decompresses. This is a key issue which bears on possible explosive behavior of the system at the vent. The assessment of the extent of oversaturation of volatiles in magma during such an eruption is a complex problem and requires numerical methods for solution. We take oversaturation to mean the amount of volatiles (wt \%) dissolved in a supersaturated melt beyond the equilibrium saturation value.

In the present study we have upgraded our former numerical model and developed codes for more realistic physical conditions of diffusive and decompressive bubble growth and quantify the contributions of each. We consider the diffusive contribution as exsolution in response only to oversaturation. Exsolution in response to equilibrium degassing while maintaining saturation during decompression is included in the decompression contribution. The fundamental mathematical treatment is similar to that of our preliminary study [Proussevitch et al., 1993b], so the fundamental equations will only be summarized here (Table 1).

A basic numerical model can be used to quantify bubble growth and magma degassing processes in a rising parcel of magma in a volcano conduit. The objectives of the model include (1) quantification of bubble growth dynamics, gas fraction evolution, and dynamics of volatile $\left(\mathrm{H}_{2} \mathrm{O}\right)$ oversaturation during magma ascent and decompression; (2) quantification of the relations between magma decompression rate and volatile oversaturation prior to and at eruption as melt continues to degas (at atmospheric pressure) after reaching the surface; and (3) estimation of the character and dynamics of energetic eruptions driven by highly oversaturated magma based on rough extrapolation from individual bubble growth to the scale of a volcanic system. These must be considered only rough estimates because of the complex rheology of multiphase media and because rhyolite foam with high gas fraction involves different boundary conditions than those

Table 1. Original System of Equations Which Has Been Solved Numerically in This Model

\begin{tabular}{|c|c|c|}
\hline Process & Equation* & $\begin{array}{l}\text { Equation } \\
\text { Number } \\
\text { Reference }\end{array}$ \\
\hline $\begin{array}{l}\text { Hydrodynamics of melt } \\
\text { surrounding the } \\
\text { bubble. Combined } \\
\text { equation of } \\
\text { momentum and } \\
\text { continuity. }\end{array}$ & $\begin{array}{l}\qquad p_{g}=p_{f}+\frac{2 \sigma}{R}+4 \eta v_{R}\left(\frac{1}{R}-\frac{R^{2}}{S^{3}}\right) \\
\text { in terms of contributions to total bubble pressure } \\
p_{g}=p_{f}+p_{\sigma}+p_{\eta}\end{array}$ & (7) \\
\hline $\begin{array}{l}\text { Mass balance at the bubble } \\
\text { interface. Diffusive } \\
\text { bubble growth. }\end{array}$ & $\frac{d}{d t}\left(R^{3} \rho_{g}\right)=3 R^{2} D \rho\left(\frac{\partial c}{\partial r}\right)_{r=R}$ & (9) \\
\hline \multirow[t]{2}{*}{$\begin{array}{l}\text { Volatile diffusion in the } \\
\text { melt. }\end{array}$} & $\frac{\partial c}{\partial t}+v_{r} \frac{\partial c}{\partial r}=D\left(\frac{\partial^{2} c}{\partial r^{2}}+\frac{2}{r} \frac{\partial c}{\partial r}\right)$ & $(11 b)$ \\
\hline & Boundary Conditions & \\
\hline $\begin{array}{l}\text { Initially uniform volatile } \\
\text { distribution. }\end{array}$ & $c(r, 0)=c_{0}$ at $r>R$ and $\mathrm{t}=0$ & $(12 a)$ \\
\hline $\begin{array}{l}\text { Impermeability of outer } \\
\text { cell border. }\end{array}$ & $\left(\frac{\partial c}{\partial r}\right)_{r=S}=0$ at $t \geq 0$ & $(12 b)$ \\
\hline $\begin{array}{l}\text { Henry's law of gas } \\
\text { solubility on the } \\
\text { bubble interface }\end{array}$ & $c(R, t)=c_{R}=\left|K_{h} p_{g}\right|^{1 / n}$ at $r=R$ and $t>0$ & $(12 c)$ \\
\hline $\begin{array}{l}\text { Ambient pressure. It refers } \\
\text { to constant } \\
\text { decompression rate. }\end{array}$ & $p_{t}=\rho g\left(h_{0}-v_{h} t\right)$ & This paper \\
\hline $\begin{array}{l}\text { For details of numerica } \\
\text { Proussevitch et al. [1993b]. } \\
\quad * \text { Notation is } p_{g}, p_{f}, p_{\sigma} \text { a } \\
\text { bubble and elementary cell s } \\
\text { melt densities, accordingly; } \\
\text { spherical coordinates; } K_{h}, \mathrm{H} \\
\text { initial magma ascent velocity } \\
\quad \text { Reference is Proussevit }\end{array}$ & $\begin{array}{l}\text { methodology and application to degassing at various co } \\
\text { nd } p_{\eta} \text {, bubble, ambient, surface tension and dynamic pressures } \\
\text { phere radii, accordingly; } \sigma \text {, surface tension; } \eta \text {, dynamic visco } \\
t \text {, time; } c \text {, concentration; } D \text {, diffusion coefficient of water; } \\
\text { enry's law solubility constant; } g \text {, gravity acceleration; } h_{0} \text {, initial } \\
\text { ch et al. }[1993 b] \text {. }\end{array}$ & $\begin{array}{l}\text { pressures, } \\
\text { ringly; } R \text { and } \\
\text { tance variable } \\
\text { ma depth; and }\end{array}$ \\
\hline
\end{tabular}


used in our bubble growth model [Bagdassarov and Dingwell, 1993]. Nevertheless, despite these limitations, some useful qualitative estimates can be made in this regard.

While the results of the present numerical model cannot directly predict volcanic activity, it is hoped that increasingly realistic numerical models can contribute to better understanding of eruption mechanisms and styles, and eventually lead to better prediction of explosive eruption timing, energetics, and consequent hazards.

\section{Model Conditions and Constraints}

The numerical model considers individual bubble growth dynamics. The dynamics of large volcanic systems are simply treated as the sum of the individual bubbles therein, despite any neglected differences in boundary conditions. Because the individual bubble growth model is robust, but the extension to large scale systems is only qualitative, we will discuss these two scales separately.

\section{Individual Bubble Growth Model}

The individual bubble growth model includes our previous (instantaneous decompression) model as a subroutine of the more complex linear decompression formulation. The conditions for the individual bubble growth model (Figure 1) are summarized as follows [Proussevitch et al., 1993b]:

1. A single bubble-melt system has spherical symmetry and is considered as an elementary cell of the large magmatic system. The effect of the difference between the spherical and real polygonal shape of the elementary cell is

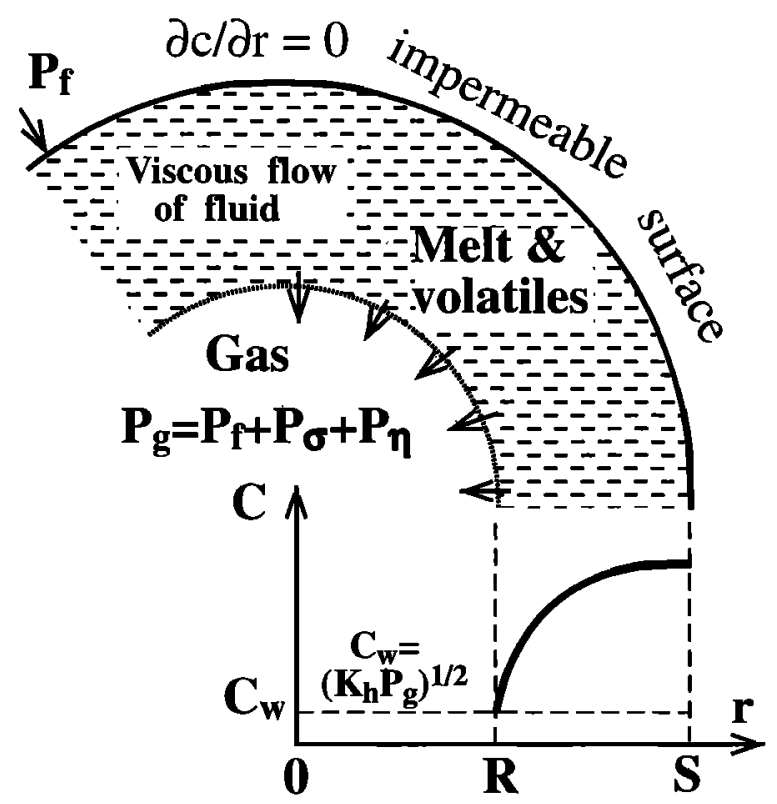

Figure 1. The numerical model for the individual bubble growth considers it as an elementary cell for a large magmatic system. The bubble is surrounded by finite volume of melt as specified by spacing of neighboring nucleation sites, and it grows due to diffusive influx of oversaturated volatiles caused by reduction of ambient (hydrostatic) pressure depending on decompression rate. For more information on bubble pressure terms and concentration profiles, see Table 1 and text.
2 orders of magnitude smaller than the main bubble growth effects and can therefore be neglected.

2. Each bubble is surrounded by a finite volume of melt, as specified by spacing of nucleation sites.

3. Bubbles grow in response to diffusive influx of oversaturated volatiles due to reduction of ambient (hydrostatic) pressure. Diffusivity is based on measured values in hydrous melts, and is considered constant throughout magma ascent and degassing. While there may be significant errors in such measurements, the coupling of diffusive and decompressive bubble growth is not sensitive to the value of the diffusivity coefficient.

4. Total pressure within each bubble consists of ambient, surface tension, and dynamic contributions.

5. Ambient pressure depends on magma ascent rate and controls volatile solubility decrease with time.

6. Various additional conditions include the fluid dynamics of the melt around each bubble, advective species flux which alters volatile concentration gradients for diffusion, variable volatile saturation on the bubble interface in equilibrium with total pressure within the bubble, and several other factors.

The individual bubble growth model extends the previous analysis in that the main module of the new model code includes a linear decompression routine reflecting decreasing ambient pressure during magma ascent with constant decompression rate (Table 1). Ascent rates are specified as the rate at the base of the conduit, unaffected by reduction in magma bulk density in response to bubble growth.

\section{Multiple-Bubble Systems}

It is instructive to concatenate the results of many single-bubble systems in preparation for future volcanic simulations. Mass conservation in a rising system with an open top containing multiple growing bubbles demands that volume increase upward. This is because growth of each bubble is accommodated by displacement of overlying melt (and bubbles). In this and subsequent sections, we consider a model magmatic system which has some, but not all, attributes of a volcanic system. We designed our model system so as to most clearly reveal the manifestations of the interaction between diffusive and decompressive bubble growth, as described above. For instance. we did not allow feedback between bubble growth and decompression rate but held the latter at various constant values. We also disallowed nucleation in response to oversaturation during ascent so that no discontinuities in volatile concentration gradients would arise in mid-ascent. The conditions for a large multiplebubble model system include those of each individual bubble and also include the larger scale conditions as follows:

1. Two major melt compositions (basalt and rhyolite) are considered. The properties of basaltic and rhyolitic melts and some general parameters and constants used in the model are listed in Table 2.

2. Magma ascent rate is defined such that there is a constant rate of decompression, $d P / d t$. While this is surely not true in volcanic eruptions, no generally applicable acceleration history of magma flow within a volcanic conduit has ever been documented [Toramaru, 1989]. At 
Table 2. Properties of Rhyolitic and Basaltic Magmas at $1000^{\circ}$ and $1200^{\circ} \mathrm{C}(0.1 \mathrm{MPa})$, Accordingly, and Other Constants Used in the Numerical Simulations

\begin{tabular}{|c|c|c|c|c|}
\hline Symbol & Property & Value & Units & Reference \\
\hline \multicolumn{5}{|c|}{ Rhyolitic Melt } \\
\hline$\rho$ & Density & 2200 & $\mathrm{~kg} \mathrm{~m}^{-3}$ & 1 \\
\hline$\eta$ & Viscosity & $10^{6}$ & Pas & 2 \\
\hline $\mathrm{D}_{\mathrm{H}_{2} \mathrm{O}}$ & $\mathrm{H}_{2} \mathrm{O}$ diffusivity & $3 \times 10^{-11}$ & $m^{2} s^{-1}$ & $3 a, 3 b$ \\
\hline$K_{h}$ & Henry constant & $1.6 \times 10^{-11}$ & $\mathrm{~Pa}^{-1}$ & 4 \\
\hline$\sigma$ & Surface tension & 0.32 & $\mathrm{~N} \mathrm{~m}^{-1}$ & 5 \\
\hline \multicolumn{5}{|c|}{ Basaltic Melt } \\
\hline$\rho$ & Density & 2600 & $\mathrm{~kg} \mathrm{~m}^{-3}$ & 6 \\
\hline$\eta$ & Viscosity & 50 & Pas & 7 \\
\hline$D_{\mathrm{H}_{2} \mathrm{O}}$ & $\mathrm{H}_{2} \mathrm{O}$ diffusivity & $2 \times 10^{-9}$ & $m^{2} s^{-1}$ & 8 \\
\hline$K_{h}$ & Henry constant & $9 \times 10^{-12}$ & $\mathrm{~Pa}^{-1}$ & 4 \\
\hline$\sigma$ & Surface tension & 0.36 & $\mathrm{~N} \mathrm{~m}^{-1}$ & 5 \\
\hline \multicolumn{5}{|c|}{ Constants and Parameters } \\
\hline$B$ & Gas constant & 8.31 & $\mathrm{~J} \mathrm{~K}^{-1} \mathrm{~mol}^{-1}$ & \\
\hline$M_{\mathrm{H}_{2} \mathrm{O}}$ & Molecular weight & $18 \times 10^{-3}$ & $\mathrm{~kg} \mathrm{~mol}^{-1}$ & \\
\hline$R_{\mathrm{O}}$ & Nuclear radius & $10^{-5}$ & $\mathrm{~m}$ & \\
\hline$S_{0}$ & Separation & $10^{-3}$ & m & \\
\hline
\end{tabular}

References are 1, Clark et al. [1987]; 2, Shaw [1972]; 3a, Karsten et al. [1982]; 3b, Zhang et al. [1991]; 4, Burnham [1975]; 5, Proussevitch and Kutolin [1986]; 6, Murase and McBirney [1973]; 7, Shaw et al. [1968]; 8, Zhang and Stolper [1991].

the very least, rapid growth in gas fraction must produce significant acceleration during foam development near the vent [Wilson et al., 1980] in order to conserve mass flux, beyond the acceleration associated with bulk density decrease and the constant $d P / d t$ condition. Thus bubbles grow in a feedback loop with decompression rate, as each is driven, in part, by the other. The problem of acceleration history of each bubble from nucleation to eruption is a complex problem that we will leave to a subsequent study. We maintain constant decompression rate in the model to allow the clear identification and quantification of the processes of diffusive and decompressive bubble growth.

3. Starting depths of magma rise have been arbitrarily chosen to be 4 and $1 \mathrm{~km}$, representing deep and shallow magma storage reservoirs, respectively. The analysis would be the same for any magma starting depth.

4. At the initial depth, each bubble has a radius close to nuclear size. We do not consider the problem of nucleation but allow already nucleated bubbles (with a specified number density) to grow as the melt becomes oversaturated. The number density remains constant throughout bubble growth if it is defined as number of bubbles per mass of melt, rather than volume of the entire system.

5. We assume that the magma is saturated with water at its initial depth, according to the solubility curve. As the melt rises, and ambient (hydrostatic) pressure decreases, and the melt becomes oversaturated leading to melt degassing and bubble growth. The extent of oversaturation depends on the relative rates of magma rise (decompression) and volatile diffusion.

6. The volatiles exsolve into bubbles and do not leave the magmatic system (through country rock) during magma rise. Thus the volatiles are partitioned between bubbles and melt until complete exsolution at atmospheric pressure.

7. If the melt is not degassed to equilibrium at $0.1 \mathrm{MPa}$ by the time it reaches the surface, the model assumes that the melt continues to degas at atmospheric pressure until exsolution is complete. In this case, bubbles grow by diffusive increase of gas mass but not by decompression.

Based on the above conditions and constraints, physical and mathematical procedures were applied to develop Fortran codes for running numerical "experiments." Using standard input parameters from Table 2 in combination with one of the chosen starting depths and with a specified starting ascent rate, the numerical model provides us with the following output parameters as a function of time: depth, bubble radius, average volatile oversaturation in the melt, gas fraction in the system, thickness of the bubble wall, pressure terms within the bubble (ambient, surface tension, and dynamic terms), and volatile concentration profile across the bubble wall. These output parameters are used to quantify bubble growth and degassing processes in a rising and decompressing parcel of magma.

It should be noted that foam disruption [Cashman and Mangan, 1994; Proussevitch et al., 1993a] is not considered in this analysis. For all model runs, the final gas fraction in the system at atmospheric pressure is about 

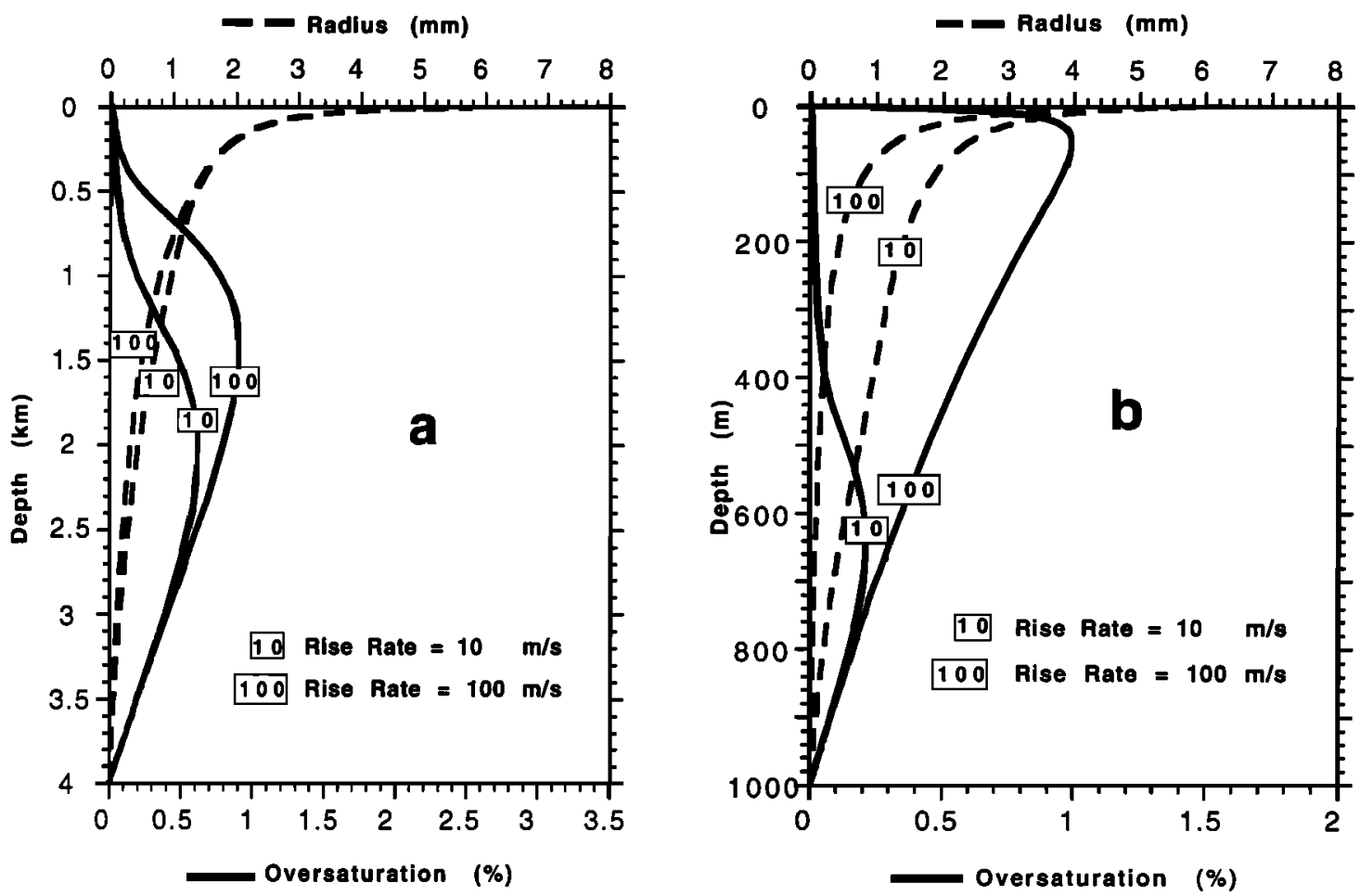

Figure 2. Bubble growth and $\mathrm{H}_{2} \mathrm{O}$ oversaturation dynamics for model runs with basaltic magma. Initial depths (and pressures) are (a) $4 \mathrm{~km}(102 \mathrm{MPa}$ ) and (b) $1 \mathrm{~km}(25.5 \mathrm{MPa})$. Initial concentrations at saturation are $3.03 \mathrm{wt} \%$ and $1.52 \mathrm{wt} \%$, respectively. Rise rates always refer to rate at base of conduit. As a bubble grows during linear decompression, rise rate increases as overlying magma bulk density decreases.

$99.8 \%$. In actual volcanic systems, there can be neither bubbles nor foam at this gas fraction because the foam would have disrupted into gassy spray (leading to pyroclast formation) at some lesser gas fraction. The threshold value is commonly taken to be around $80 \%$ because this is the vesicularity limit for most common volcanic scoria and pumice, but there is considerable variation [Gardner et al. , 1991; Houghton and Wilson, 1989; Mangan et al., 1993; Thomas et al., 1994]. In our present model, the melt continues to degas after foam disruption as if there was no change in bubble geometry, so that dissolved volatile concentration evolves toward equilibrium with ambient pressure, and finally with atmospheric pressure. Fortran codes for the numerical model are available from authors upon request.

\section{Results for Basaltic System}

A number of model runs were performed for the basaltic system with initial magma ascent rates between 0.1 and $100 \mathrm{~m} / \mathrm{s}$. These ascent rates apply to the magma at depth before significant bubble growth. Bubble growth causes great accelerations so that much higher rates are observed at the vent [Sparks, 1986]. The results of model runs are illustrated in Figure 2. It was found that for typical ascent rates between a few meters per second and tens of meters per second [Head and Wilson, 1987] the melt maintains equilibrium volatile concentration as it decompresses. Only in the case of very small bubbles is there even a minor delay of bubble growth and degassing [Sahagian et al., 1994; Sparks, 1994] which leads to oversaturation of about $0.6 \mathrm{wt} \%(10 \mathrm{~m} / \mathrm{s}$ ascent rate $)$. This time delay arises from surface tension and viscous resistance to bubble growth at small bubble sizes. For typical ascent rates of less than $10 \mathrm{~m} / \mathrm{s}$, the dissolved volatiles are in equilibrium with gas in the bubbles, and the bubble growth curve is not affected by kinetic factors.

Only for extreme ascent rates $(100 \mathrm{~m} / \mathrm{s})$ is there any oversaturation depending on the starting depth of magma rise (maximum oversaturation of $0.9 \%$ and $1.0 \mathrm{wt} \%$ which occur at depths of $1.5 \mathrm{~km}$ and $60 \mathrm{~m}$ for the 4-and 1 $\mathrm{km}$ starting depths, respectively) (Figure 2). These modeled values of $\mathrm{H}_{2} \mathrm{O}$ oversaturation are in close agreement with independent analyses [Greenland, 1988; Head and Wilson, 1987]. Such extreme ascent rates are possible in natural volcanic systems. Lava fountain heights of $400 \mathrm{~m}$ were observed during the Pu'u O'o, Kilauea eruption of 1984 [Wolfe et al., 1987] which implies a magma ascent rate of about $100 \mathrm{~m} / \mathrm{s}$ [Head and Wilson, 1987]. However, even for this extreme ascent rate, volatile concentration in the melt can maintain equilibrium with decreasing pressure so that very near the vent, there is virtually no additional exsolution, and bubble growth is dominated by decompressive expansion.

\section{Results for Rhyolitic Systems}

Diffusive transport properties of rhyolitic magma (Table 2) are very different from those of basaltic magma. This leads to contrasting degassing behavior, especially in the upper part of the conduit [Sparks et al., 1994]. Starting depths for rhyolitic magma rise were chosen as 4 and $1 \mathrm{~km}$ 

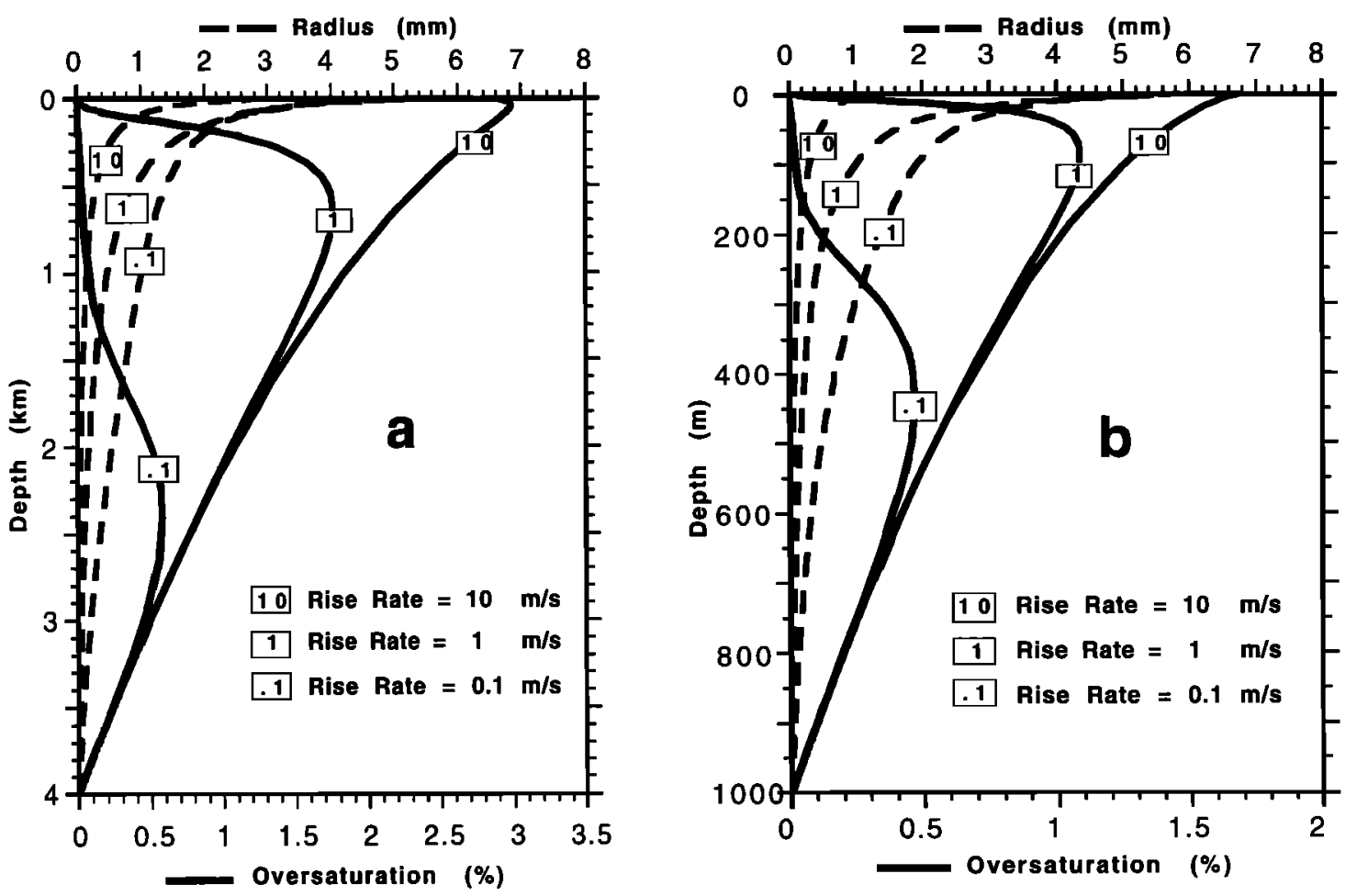

Figure 3. Bubble growth and $\mathrm{H}_{2} \mathrm{O}$ oversaturation dynamics for model runs with rhyolitic magma. Initial depths (and pressures) are (a) $4 \mathrm{~km}(86.3 \mathrm{MPa})$ and (b) $1 \mathrm{~km}(21.6 \mathrm{MPa})$. Initial concentrations at saturation are $3.72 \mathrm{wt} \%$ and $1.86 \mathrm{wt} \%$, respectively.

[Marsh, 1989; Williams and McBirney, 1979]. The numerical model results are very sensitive to the choice of magma decompression rate. We refer to ascent rate as that of the magma before or below the level of significant bubble growth, and adjust this rate to maintain constant $d P / d t$ throughout modeled bubble growth. Ascent rate is chosen on the basis of data from field measurements and estimates of magma discharge during various eruptions of silicic volcanoes. The highest rates are found for energetic Plinian eruptions. These are 2 and $1 \mathrm{~m} / \mathrm{s}$ for initial and intermediate episodes of the Bishop Tuff eruption [Gardner et al., 1991], $3 \mathrm{~m} / \mathrm{s}$ for the 79 A.D. Vesuvius eruption [ Carey and Sigurdsson, 1987; Sigurdsson et al., 1990], and $7 \mathrm{~m} / \mathrm{s}$ for the 1980 Mount St. Helens eruption [Carey et al., 1990]. The same range of rates follows from modeling of magma withdrawal from crustal reservoirs [Spera , 1984; Trial et al., 1992] and from estimates on the basis of fluid inclusions from the Bishop Tuff [Anderson, 1991] for comparable initial depths and ascent rates. If the actual conduit radius is significantly smaller than that of the vent, inferred maximum magma ascent rates would be several times higher than those cited above. We have conducted a number of numerical model runs for initial ascent rates of 0.01 to $10 \mathrm{~m} / \mathrm{s}$ in an attempt to quantify bubble growth and degassing dynamics in magmatic systems.

The character of degassing of the rhyolitic system can vary widely, depending on magma initial ascent rate (Figure 3). We can distinguish four different degassing styles on the basis of volatile oversaturation at eruption (Table 3):

1. Ascent rates under $10 \mathrm{~cm} / \mathrm{s}$. For slow rates of magma rise, there is no volatile oversaturation as the magma approaches the vent (Figure 3). However, there are some variations in oversaturation history for different slow ascent rates. For example, at $1 \mathrm{~cm} / \mathrm{s}$ there is never any water oversaturation, while for $10 \mathrm{~cm} / \mathrm{s}$, there is oversaturation of 0.5 and $0.6 \mathrm{wt} \% \mathrm{H}_{2} \mathrm{O}$ at depths of 0.4 and $2.3 \mathrm{~km}$ for the starting depths of 1 and $4 \mathrm{~km}$ respectively (Figure 3 ). In either case, the melt comes to equilibrium before reaching the vent, so the dominant bubble growth mechanism near the surface is decompression.

2. Ascent rates between 0.1 and $1 \mathrm{~m} / \mathrm{s}$. In this range of initial ascent rates, there is virtually no oversaturation at the surface, but there is significant oversaturation at shallow depths in the volcanic conduit $(1.1 \mathrm{wt} \%$ at $100 \mathrm{~m}$ depth) (Figure 3). With this level of oversaturation at such shallow depth, eruption may be more energetic than would predicted for this ascent rate range if there were no regard for the evolution of oversaturation with magma rise. The implications of this will be addressed below. As is the case for lower ascent rates, bubble growth in the vent is predominantly caused by decompression.

3. Ascent rates between 1 and $10 \mathrm{~m} / \mathrm{s}$. In this range of initial ascent rates, rhyolitic melt erupts with significant levels of water oversaturation. However, the maximum oversaturation is still at some shallow depth beneath the vent (200 to a few meters ). For example, for an ascent rate of $5 \mathrm{~m} / \mathrm{s}$, maximum oversaturation $\left(2.5 \mathrm{wt} \% \mathrm{H}_{2} \mathrm{O}\right.$ ) occurs at a depth of $100 \mathrm{~m}$. Oversaturation at the vent can vary between 0 and 3 wt $\% \mathrm{H}_{2} \mathrm{O}$ ( 2.2 for $5 \mathrm{~m} / \mathrm{s}$ ascent rate). Diffusive bubble growth near and at the vent is extremely rapid so that the diffusive contribution to bubble growth 
Table 3. Degassing, Bubble Growth, and Volcanic Eruption Character for Different Initial Rise Rates of Rhyolitic Magma

\begin{tabular}{|c|c|c|c|}
\hline Rise Rate & $\begin{array}{l}\text { Oversaturation at the Moment } \\
\text { Melt Reaches the Surface }\end{array}$ & $\begin{array}{l}\text { Maximum Oversaturation and } \\
\text { Its Depth }\end{array}$ & $\begin{array}{l}\text { Mechanism of Bubble Growth } \\
\text { Near or at the Vent }\end{array}$ \\
\hline under $10 \mathrm{~cm} / \mathrm{s}$ & none & $\begin{array}{l}\text { up to } 1 \mathrm{wt} . \% \\
\text { at } 1.5 \mathrm{~km}\end{array}$ & decompression \\
\hline $0.1-1 \mathrm{~m} / \mathrm{s}$ & very small & $\begin{array}{l}\text { up to } 2.3 \mathrm{wt} . \% \\
\text { at } 200 \mathrm{~m}\end{array}$ & $\begin{array}{l}\text { mainly } \\
\text { decompression }\end{array}$ \\
\hline $1-10 \mathrm{~m} / \mathrm{s}$ & $0-3$ wt. $\%$ & $\begin{array}{l}>2.5 \mathrm{wt} . \% \text { at depth } \\
\text { under } 200 \mathrm{~m}\end{array}$ & $\begin{array}{l}\text { decompression as } \\
\text { well as diffusion }\end{array}$ \\
\hline $10 \mathrm{~m} / \mathrm{s}$ and over & $\begin{array}{l}3.5 \mathrm{wt} . \% \text { or equal to } \\
\text { saturation on starting depth of } \\
\text { magma rise }\end{array}$ & the surface & diffusion \\
\hline
\end{tabular}

Starting depth of magma rise is $4 \mathrm{~km}$. Volatile is $\mathrm{H}_{2} \mathrm{O}$. Initial rise rates at base of conduit, before bubble growth

rate becomes comparable to the decompressive contribution.

4. Ascent rates greater than $10 \mathrm{~m} / \mathrm{s}$. High initial ascent rates lead to extremely energetic eruptions caused by explosive shallow degassing. Some data and field measurements suggest the possibility of such ascent rates in nature [Carey and Sigurdsson, 1987]. For these high ascent rates, silicic magma does not significantly degas until it reaches the surface regardless of magma starting depth. Thus oversaturation at the vent is approximately the water saturation value at the starting depth. For example, for an ascent rate of $10 \mathrm{~m} / \mathrm{s}$ and starting depth of $4 \mathrm{~km}$ (saturated with $3.72 \mathrm{wt} \% \mathrm{H}_{2} \mathrm{O}$ ), oversaturation at the vent is $3.0 \mathrm{wt} \%$ (Figure 3). High eruptive dissolved water concentrations of $4 \mathrm{wt} \%$ and greater have been suggested for explosive Plinian eruptions [Anderson et al., 1989; Dunbar and Kyle, 1992; Eichelberger and Westrich, 1981; Melson et al., 1990; Newman et al., 1986]. For high decompression rates, maximum oversaturation is at the surface, and the dominant bubble growth mechanism is diffusion of volatiles into the bubble at atmospheric pressure. Because there is no significant degassing of the melt en route to the surface for such high decompression rates, the melt is already at its maximum possible oversaturation, and increasing decompression rate cannot significantly increase oversaturation. However, greater starting depth can increase surface oversaturation and consequent bubble growth dynamics causing the most energetic explosive eruptions.

A scenario of high oversaturation at the surface brings into question our condition of no further bubble nucleation during magma rise. This is the most likely case for inconduit nucleation which would lead to a reduction of the average distance traveled by volatiles and thus oversaturation. We do not allow this in our model because the complexities introduced by the additional degree of freedom would obscure the processes of decompression and diffusion we wish to highlight. However, this effect may be partially offset by our artificial condition of constant decompression rate. Whereas some energetic silicic eruptions may be supersonic at the vent, we maintain a maximum case of $10 \mathrm{~m} / \mathrm{s}$. If we were to allow magma and bubble decompression rate to reach near realistic values, the time available for nucleation and diffusion would be greatly reduced, likely more than offsetting the effect of late-stage nucleation. Quantification of this is left for subsequent studies.

It is interesting to note that at depths where bubbles are very small (postnucleation) there is very little bubble growth regardless of magma ascent rate (Figure 3). Bubble growth differences due to differences in decompression rate become apparent only after bubbles reach a radius of about $0.5 \mathrm{~mm}$. This suggests that the melt does not begin to degas at a significant rate until bubbles reach this threshold radius and bubble separation distance (wall thickness) is reduced. This geometrical effect, in combination with very low oversaturation at these depths, makes for sluggish diffusion of volatiles into the bubbles. This applies to both rhyolitic and basaltic systems (Figure 2). In real volcanic systems with nucleation and interactions between bubble growth and decompression rate, the threshold radius is effectively reduced by high oversaturation buffered by nucleation, as a result of rapid ascent rates in upper levels of the conduit.

Figure 4 illustrates bubble growth dynamics near and at the vent, and after eruption when the melt degasses at constant atmospheric pressure. Regardless of decompression rate, there is very rapid bubble growth at the vent. For low ascent rates, bubble growth at the vent is caused solely by decompression (note low oversaturation for $0.1 \mathrm{~m} / \mathrm{s}$ case in Figure 4). At high magma ascent rates, the primary mechanism for bubble growth is oversaturation-induced diffusion of volatiles into bubbles. In this case, when magma is at the surface (dimensionless time $>1.0$ ), the situation approximately reduces to the simpler case of oversaturation degassing at atmospheric pressure considered in our preliminary study [Proussevitch et al., 1993b].

\section{Conclusions}

Our simple parametric model reveals some of the characteristics of the processes which control bubble growth in volcanic systems. The relationship between diffusive and decompressive bubble growth depends on 


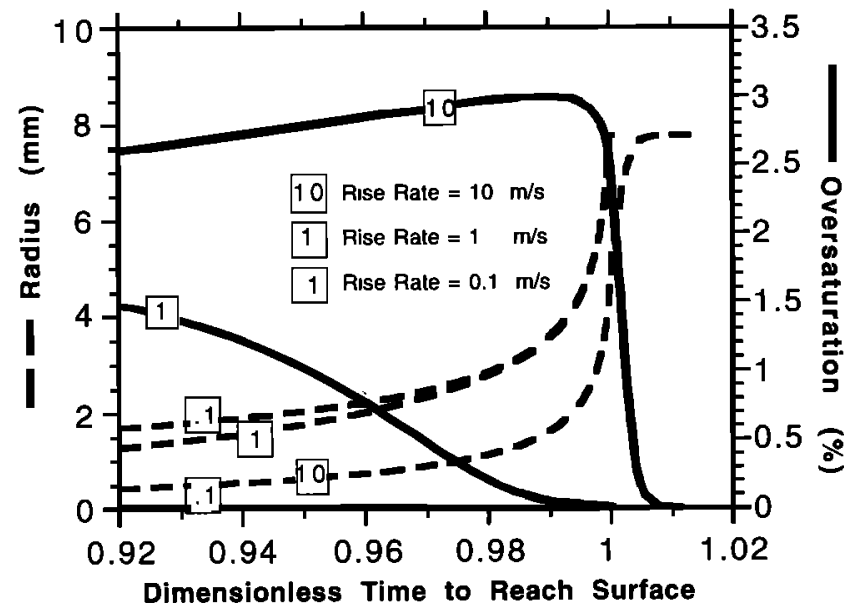

Figure 4. Bubble growth and $\mathrm{H}_{2} \mathrm{O}$ oversaturation versus dimensionless time to reach the surface for rhyolitic model runs starting at $4 \mathrm{~km}$. Note that most bubble growth and magma degassing occurs near or at the vent (vent is at time=1).

decompression rate as well as various magma parameters. The simple elementary cell geometry with a finite volume of melt around each bubble and characteristic number density defined by initial cell radius allows us to extend our analysis and make some inferences regarding large-scale processes in multiple-bubble systems. We account for the growth of multiple bubbles in a horizontal layer across the conduit and maintain constant decompression rate and neglect effects such as variations in rheology for a twophase medium or inertial effects that may arise at high accelerations. This artificial condition causes modeled vent velocities to be much less than those in natural systems which have more cylindrical geometries and in which growth and decompression rate are in constant positive feedback. The feedback between interacting bubble growth dynamics, decompression rate, and conduit geometry is a complex problem to be addressed in a subsequent study.

Several conclusions can be drawn on the basis of our simple parametric model. These bear on the processes which occur in volcanic systems but do not represent an attempt to simulate any natural system, as explained above.

1. Volatile (water) concentration in basaltic melt reaches equilibrium with ambient pressure long before it reaches the surface regardless of initial ascent rate (even up to $100 \mathrm{~m} / \mathrm{s}$ ).

2. Volatile concentration in rhyolitic melt reaches equilibrium before eruption if its initial ascent rate is less than $0.1 \mathrm{~m} / \mathrm{s}$.

3. If the initial ascent rate of rhyolitic melt is greater than $10 \mathrm{~m} / \mathrm{s}$, the model indicates that it erupts before any appreciable degassing can occur, and thus erupts highly oversaturated, the extent of which depends on the starting concentration of volatiles dissolved in the melt. In a natural system, the decompression rate would be much greater at the vent, greatly increasing oversaturation. However, this increase would be at least partially compensated by latestage nucleation in response to the high oversaturation. The highly oversaturated conditions may produce explosive volcanism.

4. In all cases of basaltic or rhyolitic magmas at reasonable decompression rates, water degassing does not even begin until the magma rises to at least $1500-200 \mathrm{~m}$ (depending on starting depth of rise).

5. Our simple model results may serve as a basis for expansion to more complex and realistic models involving acceleration histories of each bubble in the system, nucleation, feedback between bubble growth dynamics, decompression rate, and conduit geometry, and the thermal effects of bubble growth [Sahagian and Proussevitch, 1996].

Acknowledgments. The authors are grateful to A.T. Anderson for helpful discussions and comments, and to $M$. Rutherford and Y. Zhang for insightful reviews. This research was supported by NSF grant EAR-9496287.

\section{References}

Anderson, A.T.J., Hourglass inclusions: Theory and application to the Bishop Rhyolitic Tuff, Am. Mineral., 76, 530-547, 1991.

Anderson, A.T.J., C.M. Skirius, F. Lu, and A.M. Davis, Preeruption gas content of Bishop Plinian rhyolitic magma, Geol. Soc. Am. Abstr. Programs, 21, A270, 1989.

Bagdassarov, N.S., and D.B. Dingwell, Deformation of foamed rhyolites under internal and external stresses: An experimental investigation, Bull. Volcanol., 55, 147-154, 1993.

Bottinga, Y., and M. Javoy, MORB degassing: Bubble nucleation, J. Geophys. Res. , 95, 5125-5132, 1990a.

Bottinga, Y., and M. Javoy, MORB degassing: Bubble growth and ascent, Chem. Geol., 81, 225-270, 1990b.

Burnham, C.W., Water in magmas: A mixing model, Geochim. Cosmochim. Acta, 39, 1077-1084, 1975.

Carey, S., and H. Sigurdsson, Temporal variations in column height and magma discharge rate during the 79 A.D. eruption of Vesuvius, Geol. Soc. Am. Bull., 99, 303-314, 1987.

Carey, S.N., H. Sigurdsson, and J.E. Gardner, Variations of column height and magma discharge during the May 18, 1980 eruption of Mount St. Helens, J. Volcanol. Geotherm. Res., 43, 99-112, 1990.

Cashman, K.V., and M.T. Mangan, Physical aspects of magma degassing, II, Constraints on vesiculation processes from textural studies of eruptive products, in Volatiles in Magmas, edited by M.R. Carroll, and J.R. Holloway, pp. 446-478, Mineral. Soc. of Am., Washington, D. C., 1994.

Clark, S., F.J. Spera, and D.A. Yuen, Steady state doublediffusive convection in magma chambers heated from below, in Magmatic Processes: Physiochemical Principles, edited by B.O. Mysen, Geochem. Soc., Washington, D. C., pp. 289-305, 1987.

Dobran, N., Nonequilibrium flow in volcanic conduit and applications to the eruptions of Mount St. Helens on May 18, 1980 and Vesuvius on AD79, J. Volcanol. Geotherm. Res., 49, 285-311, 1992.

Dunbar, C., and P. Kyle, Volatile contents of obsidian clasts in tephra from the Taupo volcanic zone, New Zealand: Implications to eruptive processes, J. Volcanol. Geotherm. Res., 49, 127-145, 1992.

Eichelberger, J.C., and H.R. Westrich, Magmatic volatiles in explosive rhyolitic eruptions, Geophys. Res. Lett. , 8, 757-760, 1981.

Gardner, J.E., H. Sigurdsson, and S.N. Carey, Eruption dynamics and magma withdrawal during the plinian phase of the Bishop Tuff eruption, Long Valley Caldera, J. Geophys. Res. 96, 8097-8111, 1991 .

Greenland, L., Gases from the 1983-84 East Rift eruption, in The Puu Oo Eruption of Kilauea Volcano, Hawaii: Episodes 1 Through 20, January 3, 1983, Through June 8, 1984, edited by E.W. Wolfe, pp. 145-154, U. S. Geol. Survey, Denver, CO, 1988.

Head, J., and L. Wilson, Lava fountain heights at Puu Oo, Kilauea, Hawaii: Indicators of amount and variations of 
exsolved magma volatiles, J. Geophys. Res., $92,13,715-$ $13,719,1987$

Houghton, B., and C. Wilson, A vesicularity index for pyroclastic deposits, Bull. Volcanol., 5I, 451-462, 1989.

Hurwitz, S., and $O$. Navon, Bubble nucleation in rhyolitic melts: Experiments at high pressure, temperature, and water content, Earth Planet. Sci. Lett., J22, 267-280, 1994.

Jaupart, C., and S. Vergniolle, Laboratory models of Hawaiian and Strombolian eruptions, Nature, 33I , 58-60, 1988.

Karsten, J., J. Holloway, and J. Delaney, lon microprobe studies of water in silicate melts: Temperature-dependent water diffusion in obsidian, Earth Planet. Sci. Lell., 59, 420-428, 1982.

Mader, H.M., Y. Zhang, J.C. Phillips, and R.S.J. Sparks, Experimental simulations of explosive degassing of magma, Nature, 372 , 85-88, 1994.

Mangan, M.T., K.V. Cashman, and S. Newman, Vesiculation of basaltic magma during eruption, Geology, 21, 157-160, 1993.

Marsh, B.D., Magma chambers, Annu. Rev. Earth Planet. Sci. 17, 439-474, 1989

Melson, W.G., J.F. Allan, D.R. Jerez, J. Nelen, M.L. Calvache, S.N. Williams, J. Fournelle, and M. Perfit, Water contents, temperatures and diversity of the magmas of the catastrophic eruption of Nevado-Del-Ruiz, Columbia, November 13, 1985, J. Volcanol. Geotherm. Res., 41, 97-126, 1990.

Murase, T., and A. McBirney, Properties of some common igneous rocks and their melts at high temperature, Geol. Soc. Am. Bull. , 83, 3563-3592, 1973.

Neri, A., and F. Dobran, Influence of eruption parameters on the thermofluid dynamics of collapsing volcanic columns, $J$. Geophys. Res., 99, 11,833-11,857, 1994.

Newman, S., E. Stolper, and S. Epstein, Measurement of water in rhyolitic glasses: Calibration of an infrared spectroscopic technique, Am. Mineral. , 7I, 1527-1541, 1986.

Proussevitch, A., and V. Kutolin, Surface tension of magmatic melts (in Russian), Geol. Geophys. , 9, 58-67, 1986.

Proussevitch, A., D. Sahagian, and V. Kutolin, Stability of foams in silicate melts, J. Volcanol. Geotherm. Res., 59, 161-178, 1993a.

Proussevitch, A.A., D.L. Sahagian, and A.T. Anderson, Dynamics of diffusive bubble growth in magmas: lsothermal case, J. Geophys. Res. , 98, 22,283-22,308, $1993 \mathrm{~b}$.

Sahagian, D.L., and A.T. Anderson, Classification of Hawaiian eruption styles on the basis of mechanisms of volatile release (abstract), Eos Trans. AGU, 72 (17), Spring Meet. Suppl., 296, 1991.

Sahagian, D.L., and A.A. Proussevitch, Thermal controls on diffusive bubble growth in magmas, J. Volcanol. Geotherm. Res., in press, 1996

Sahagian, D.L., A.A. Proussevitch, and A.T. Anderson, Reply, J. Geophys. Res., 99, 17,829-17,832, 1994.

Shaw, H.R., Viscosities of magmatic silicate liquids: An empirical method of prediction, Am. J. Sci., 272, 870-895, 1972.

Shaw, H.R., T.L. Wright, K.L. Peck, and R. Okamura, The viscosity of basaltic magma: An analysis of field measurements in Makaopuhi Lava Lake, Hawaii, Am. J. Sci. $266,225-264,1968$.

Sheridan, M.F., and K.H. Wohletz, Animated computer models of volcanic eruptions, Geotimes, 37, 15-17, 1992.

Sigurdsson, H., W.C. Cornell, and S. Carey, Influence of magma withdrawal on compositional gradients during the AD 79 Vesuvius eruption, Nature, 345, 519-521, 1990.

Sparks, R.S.J., The dynamics of bubble formation and growth in magmas: A Review and analysis, J. Volcanol. Geotherm Res. $3,1-38,1978$

Sparks, R.S.J., The dimensions and dynamics of volcanic eruption columns, Bull. Volcanol., 48, 3-15, 1986.
Sparks, R.S.J., Comment on "Dynamics of diffusive bubble growth in magmas: Isothermal case" by A. A. Proussevitch, D. L. Sahagian, and A. T. Anderson, J. Geophys. Res., 99 , 17,827-17,828, 1994.

Sparks, R.S.J., J. Barclay, C. Jaupart, H.M. Mader, and J.C. Phillips, Physical aspects of magma degassing, 1, Experimental and theoretical constraints on vesiculation, in Volatiles in Magmas, edited by M.R. Carroll and J.R. Holloway, pp. 413-445, Mineral. Soc. of Am., Washington, D. C., 1994.

Spera, F.J., Some numerical experiments on the withdrawal of magma from crustal reservoirs, J. Geophys. Res., 89, 8222 $8236,1984$.

Tait, S., C. Jaupart, and S. Vergnoille, Pressure, gas content and eruption periodicity of a shallow, crystallizing magma chamber, Earth Planet. Sci. Lett., 92, 107-1 23, 1989.

Thomas, N., C. Jaupart, and S. Vergniolle, On the vesicularity of pumice, J. Geophys. Res. , 99 , 15,633-15,644, 1994.

Toramaru, A., Vesiculation process and bubble size distributions in ascending magmas with constant velocities, J. Geophys. Res., 94 , 17,523-17,542, 1989.

Toramaru, A., Numerical study of nucleation and growth of bubbles in viscous magmas, J. Geophys. Res., I00, 1913$1931,1995$.

Trial, A.F., F.J. Spera, J. Greer, and D.A. Yuen, Simulations of magma withdrawal from compositionally zoned bodies, $J$. Geophys. Res., 97 , 6713-6733, 1992.

Turcotte, D.L., H. Ockendon, J.R. Ockendon, and S.J. Cowley, A mathematical model of vulcanian eruptions, Geophys. J. Int., $103,211-217,1990$.

Valentine, G.A., K.H. Wohletz, and S.W. Kieffer, Sources of unsteady column dynamics in pyroclastic flow eruptions, $J$. Geophys. Res., $96,21,887-21,892,1991$

Vergniolle, S., and C. Jaupart, Dynamics of degassing at Kilauea volcano, Hawaii, J. Geophys. Res., 95, 2793-2809, 1990.

Williams, H., and A.R. McBirney, Volcanology, 397 pp., W.H. Freeman, New York, 1979.

Wilson, L., R.S.J. Sparks, and G.P.L. Walker, Explosive volcanic eruptions, IV, The control of magma properties and conduit geometry on eruption column behaviour, Geophys. J. R. Astron. Soc. , 63, 117-148, 1980.

Wolfe, E.W., M.O. Garcia, D.B. Jackson, R.Y. Koyanagi, C.A. Neal, and A.T. Okamura, The Puu Oo eruption of Kilauea volcano, episodes 1-20, January 3, 1983, to June 8,1984 , in Volcanism in Hawaii, edited by R.W. Decker, et al., pp. 471 508, U. S. Geol. Survey, Denver, CO, 1987.

Woods, A.W., The fluid dynamics and thermodynamics of eruption columns, Bull. Volcanol., 50, 169-193, 1988.

Woods, A.W., and C.-C.P. Caufield, A laboratory study of explosive volcanic eruptions, J. Geophys. Res., 97, 6699$6712,1992$.

Woods, A.W., and K. Wohletz, Dimensions and dynamics of coignimbrite eruption columns, Nature, 350 , 1393-1404, 1991.

Zhang, Y., and E.M. Stolper, Water diffusion in a basaltic melt, Nature, 35J , 306-309, 1991.

Zhang, Y., E. Stolper, and G. Wasserburg, Diffusion of water in rhyolitic glasses, Geochim. Cosmochim. Acta, 55, 441-456, 1991.

A. A. Proussevitch amd D. L. Sahagian, Complex Systems Research Center, Institute for the Study of Earth, Oceans, and Space, University of New Hampshire, Durham, NH 03824-3525. (e-mail: alex.proussevitch@unh.edu; dork.sahagian@unh.edu)

(Received November 6, 1995; revised March 21, 1996; accepted April 29, 1996.) 